\title{
FinANCIAL PRODUCTS USED BY SOUTH AfRICAN HOUSEHOLDS AT DIFFERENT LIFE STAGES
}

\author{
Cinzia Stedall* \\ University of South Africa \\ stedac@unisa.ac.za
}

Received: August 2014

\author{
Jan MP Venter" \\ University of South Africa \\ ventejmp@unisa.ac.za
}

Accepted: June 2015

\begin{abstract}
South African households don't save enough to ensure financial freedom after retirement. This article poses the following question: do life stages have a significant impact on the financial products used by households? The question is asked in order to identify possible interventions that could increase financial freedom. This study found that life stages have a significant impact on South African households' selection of financial products. The use of financial products for each of the levels of the financial product usage hierarchy increases as the age of the household head increases and when the size of the family increases, the only exception being single-parent families. The study indicated that financial literacy programmes should focus on young couples and young families, as there is a notable increase in their financial product usage. The study also found a very low usage of wealth management products by South African households and suggests that policymakers consider the introduction of an incentive to increase household's usage of these products.
\end{abstract}

Keywords

Life stages, financial product usage hierarchy, financial products, saving motives, savings

*Ms C Stedall is a senior lecturer in the Department of Taxation, University of South Africa, South Africa.

\#Prof JMP Venter is professor in the Department of Financial Intelligence, University of South Africa, South Africa. 


\section{INTRODUCTION}

According to the South African Reserve Bank, South African households own assets worth R9.25 trillion, with net wealth estimated at R7.7 trillion (South African Reserve Bank, 2014). Yet more than three-quarters of people who are employed will receive a retirement income that is less than a third of their pre-retirement income, and the situation is even worse when the population as a whole is considered (Masimela \& Kiniki, 2009; National Treasury, 2013). The most important reason for this is the lack of pre-retirement savings among households due to their low saving rate (Simleit, Keeton, \& Botha, 2011). Studies in the field of saving and savings behaviour found it to be a dynamic and complex system influencing household decisions.

The majority of studies investigating saving and savings behaviour used Fisher's discounted utility model (1930) and Friedman's permanent income hypothesis (1957) as the basis for the studies. Motives for saving and financial literacy were identified as the two important factors that impact on a household's saving and savings behaviour (Goodall \& King, 2010). Studies into saving motives identified several motivations or reasons for saving; some of these can exist simultaneously in a household. The importance a household places on each of these saving motives influences the financial products used (Canova, Rattazzi \& Webley, 2005; Keynes, 1936; Eriksson \& Hermansson, 2014). De Clercq and Venter (2009) and The Financial Services Board (2011:60) found that according to national and international studies, financial literacy has an impact on people's perceptions of the importance of saving as well as their knowledge of the financial products that can be used to achieve their saving objectives (saving objectives are based on the saving motives of a household). Improving people's financial knowledge will therefore help them not only to understand better why they must save but also which financial products they can use to save.

Several international financial planning associations agree that selecting the appropriate financial products (as part of a financial plan) will ensure that the household's wealth is maximised and that it meets its saving objective (for example providing post-retirement income) (Venter, 2014). Lack of financial planning could leave a person dependent on a government social grant - for example the older persons grant, which is currently Rl 350 per month (National Treasury, 2013).

Traditionally, a risk-based analysis was used as the basis for financial planning and financial product selection. Given that less than $10 \%$ of all people in South Africa will have a postretirement income sufficient to maintain their standard of living, alternative approaches need to be considered (Masimela \& Kiniki, 2009; National Treasury, 2013). Internationally, the life-stage approach to financial planning has gained ground as an alternative basis for financial planning. In the life-stage approach, financial products are selected based on current and future needs of a family instead of their perceptions on risk (Ando \& Modigliani, 1963; Goodall \& King, 2010; Modigliani \& Brumberg, 1954).

Following some exploratory work done by Venter and Stedall (2010), this article is the first to determine whether life stages have a statistically significant impact on South African households' selection of financial products. The findings reported in this article will be valuable to different role players in the South African financial services industry. Firstly, financial service regulators (for example, the Financial Services Board) will benefit, as the research will indicate on which life stage financial literacy programmes should focus in order to prevent over-indebtedness in South Africa and prevent people from falling into the debt trap. Secondly, financial product houses and banks can benefit, as the analyses could indicate areas where product development is required and gaps exist in the market. This analysis can be used to identify new clients and develop 
products to meet the clients' needs. Finally, the article can assist policymakers (for example, National Treasury) to develop saving incentives for each of the life stages, which could lead to an increase in the saving rate of the household sector.

In order to achieve the objectives of the study, the research firstly analysed studies investigating financial product selection and possible classification of financial products. This was followed by developing life stages definitions, which were used to determine whether life stages have a significant impact on the financial products used by households. In the final part of the article, an analysis of the results obtained from the 25444 respondents to determine whether life stages have a significant impact in financial product usage in South Africa will be supplied.

\section{RESEARCH OBJECTIVE AND HYPOTHESES}

The primary objective of the study is to determine if life stages have a significant influence on the financial products used by households. To achieve this objective the following hypotheses were developed.

Hypothesis 1: $\quad$ Life stages have a significant influence on the financial products used by households for each of the financial product hierarchy levels.

Hypothesis 10: Life stages do not have a significant influence on the financial products used by households for each of the financial product hierarchy levels.

Firstly, the two important concepts used in this study, namely financial product usage hierarchy and life stages, will be analysed. Thereafter, the data will be analysed by applying these concepts.

\section{FINANCIAL PRODUCT USAGE HIERARCHY}

The financial product usage hierarchy is grounded in the field of saving and savings behaviour. This section will provide an overview of development of the South African financial product usage hierarchy.

Keynes (1936) identified eight main reasons for saving, namely: precautionary, foresight, calculations, improvement, independence, enterprise, pride and avarice motives, to which Browning and Lusardi (1996) added one more motive, the down-payment motive. Since Keynes's initial study several studies into motives for saving and how these motives relate to the use of financial products have been undertaken. An analysis of these studies leads to the conclusion that although Friedman's 'permanent income hypothesis' (1957) can be applied to partly explain financial product selection, household saving behaviour is complex in nature, with various factors influencing it (Canova et al., 2005; Lindqvist, 1981; Warneryd, 1999; Venter \& Botha, 2014). Katona (1975) found that a person's ability to save and his/her willingness to save interact when savings decisions are made. To add to the complexity of the household's decision-making process Warneryd (1999) found that some of these motives are inter-related and the use of single product satisfies more than one motive simultaneously. In a more recent study, which examined the relationship between saving motives and saving behaviour, the results confirmed that emergency and retirement saving motives are important predictors of saving behaviour (Fisher \& Anong, 2012). Also important was a 'time horizon', which aids in predicting saving behaviour. 
In order to better explain household saving behaviour Lindqvist (1981) developed a saving motives hierarchy. The saving motives hierarchy consists of four levels that describe the order in which households acquire financial products as well as the types of products acquired. The first level of the saving motives hierarchy is the cash management motive, which aims to resolve shortterm financial issues. The second level of the saving motives hierarchy relates to the precautionary motive; at this level the household aims to make provision for unexpected expenditures. At the next level the focus is on the down-payment motive - for example, the accumulation of funds towards buying a house. The fourth and final level of the saving motives hierarchy is the wealth management motive, the aim of which is to invest in assets that create and maintain household wealth.

Venter and Stedall (2010) analysed the objective of the main types of financial products available in South Africa and aligned them to the objective of Lindqvist's saving motives hierarchy to develop the South African financial product usage hierarchy (see FIGURE 1).

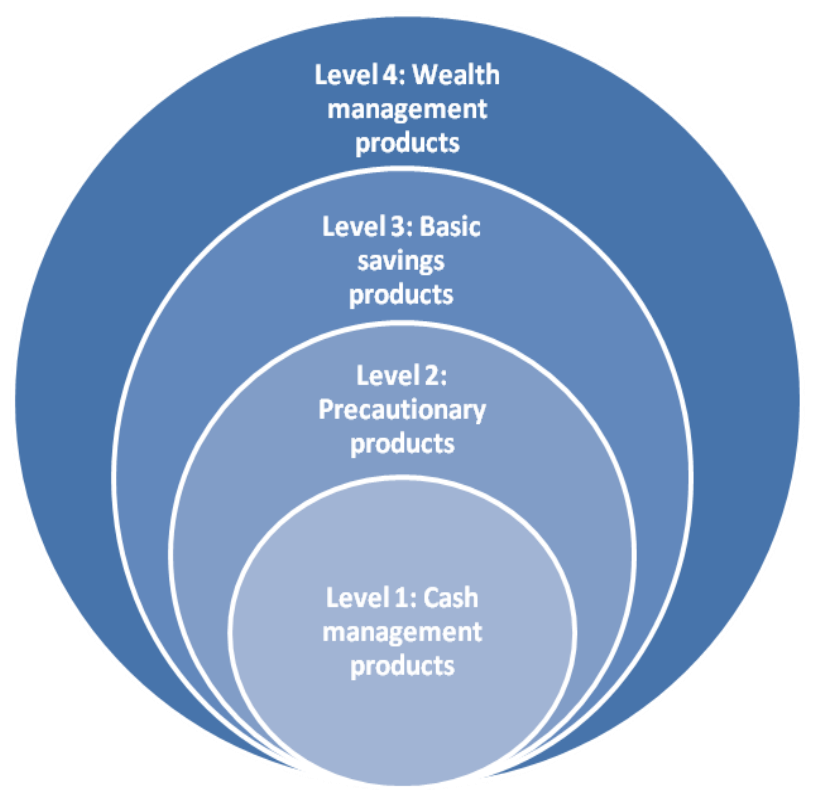

FIGURE 1: South African financial product usage hierarchy

Source: Venter \& Stedall, 2010

This study applied the South African financial product usage hierarchy to determine if life stages have a significant influence on the use of financial products. DeVaney, Anong and Whirl (2007) found that various factors can influence movement between different levels of Lindqvist's (1981) saving motives hierarchy. There were three factors that were found to be very significant - namely, the age of the household head, the size of the family and the length of the financial planning horizon.

After analysing the factors that influence the movement between the different levels of the saving motives hierarchy, it is clear that the life stages model could provide an alternative method of measuring movement between different levels in the saving motives hierarchy and the financial product usage hierarchy. 


\section{LIFE STAGES IN THE FINANCIAL SERVICES INDUSTRY}

The aim of this research is to establish if the life stage model can be applied to explain financial product usage by South African households. The principle applied in the life stages model can be linked back to Modigliani and Brumberg's (1954) lifecycle hypothesis as well as Friedman's permanent income hypothesis (1957). Applying the principles of the lifecycle and permanent income hypotheses to the human lifecycle, it is clear that people should save during the family, career and pre-retirement years to provide income after retirement (Botha, 2010).

Several studies investigating the relationship between the lifecycle hypothesis and financial product acquisition found a significant relationship between them (Baek \& Hong, 2004; Stafford, Kasulis \& Lusch, 1982; Xiao and Anderson, 1997). Later studies into this relationship found that households did not find the same relationship between the lifecycle hypothesis and financial product acquisition patterns (Bijmolt, Pass \& Vermunt, 2004).

When considering the use of life stages for analytical purposes it is important to note that no consensus exists on how to define the different life stages (Wilkie, 1994). Several definitions make use of the age of the household head and the size and composition of the family to describe the household (Murphy \& Staples, 1979).

Botha (2010) points out that as a household moves through the life stages, the composition of the household total financial needs will change. Some needs will stay constant (for example, food and clothing), some needs will increase (for example the cost of living), while others will decrease (for example, mortgage to be paid). Some of the needs of the household could be temporary in nature and fluctuating (for example, costs related to having a child at university). Several authors agreed that the life stages model could influence the financial needs of a household (Pass, Bijmolt \& Vermunt, 2007, Wheelwright, 2003:61-68).

Using the age of the household head and composition of the family the South African Advertising Research Foundation (SAARF) identified eight different life stages to be used for research purposes in South Africa (SAARF, 2014). For the purposes of this research these eight life stages will be applied, namely at-home singles, young independent singles, mature singles, young couples, young family, single-parent family, mature family and mature couples.

\section{At-home singles}

This group of people are under the age of 34 years, not married or living together and also do not have any dependent children in the household. The most important characteristic of this group is the fact that they are still living with their parents. Botha (2010) suggests that young singles' financial needs centre around maintaining liquidity.

\section{Young independent singles}

This group of people are also younger than 34 years of age, not married or living together with no dependent children in the household. However, the members of this group are no longer living with their parents.

\section{Mature singles}

Mature singles are not married or living together and also do not have any dependent children in the household. Members of this group are 35 years of age or older. 


\section{Young couples}

Young couples are defined as couples who are married or living together but do not have any dependent children in the household, with the household head being younger than 50 years of age. young couples normally experience an 'incredible burst of spending', as households shift from young single stage to the stage of young couple. Some of the financial needs during this stage were found to be buying a house and taking care of the insurance needs of the family (Pass et al., 2007).

\section{Young family}

A young family is a family where the parents are married or living together with at least one dependent child under 13 years in the household. Goodall and King (2010) explain that expenditure adjustments are made as households make the shift from young and married to a household with children, with increased expenditure for insurance, child care and saving for children's education.

\section{Single parent family}

If the household head is not married or living together but has at least one dependent child under 13 years in the household, the household is classified as single-parent family.

Divorce usually entails a significant change in the relative wealth of spouses (Fethke, 1998): usually the single persons have lower income than a married couple, as there is no dual income. As several of the household costs are fixed in nature (for example, rates and taxes), these households cannot afford to invest in financial products on a single income and still support children.

\section{Mature family}

A mature family is described as a family where the parents are married or living together, with all the dependent children in the household over the age of 13 years.

\section{Mature couples}

Mature couples are couples who are married or living together but do not have any dependent children in the household, and the head of the household is 50 years of age or older. Baek and Hong (2004) state that when people reach retirement age they start to dissave and begin to draw on their savings.

Using the life stages described in this section, analyses were performed to determine if life stage influences the use of financial products by South African households.

\section{METHODOLOGY}

The aim of this article is to determine if life stages have a significant impact on the financial products used by South African households. In order to achieve this objective the products included in the different levels of the financial product usages hierarchy were statistically analysed per life stage to determine if they have a significant impact on usage. This study makes use of household data, and it is therefore important to note that a household is described as a decision-making unit rather than an individual making a decision in isolation (Grosh \& Glewwe, 2000). 
The data used in this article was obtained from SAARF's All Media and Products Study (AMPS). AMPS is a multi-stage, area-stratified systematic probability sampling done by means of in-home face-to-face personal interviews. The sample is representative of the total South African adult population ( 15 years of age and older). The data of 25444 respondents used in the analyses was obtained from a single source survey conducted between January 2013 and December 2013 (SAARF, 2014). TABLE 1 provides a description of respondents per life stage group.

\section{TABLE 1: Respondents per life stage group}

\begin{tabular}{lcc}
\hline Life stage & $N$ & $\%$ \\
\hline At-Home Singles & 5127 & $20.2 \%$ \\
Young Independent Singles & 2552 & $10.0 \%$ \\
Single-Parent Family & 2835 & $11.1 \%$ \\
Mature Singles & 3538 & $13.9 \%$ \\
Young Couples & 1881 & $7.4 \%$ \\
Young Family & 4614 & $18.1 \%$ \\
Mature Family & 1111 & $4.4 \%$ \\
Mature Couples & 3786 & $14.9 \%$ \\
\hline Total & 25444 & $100.0 \%$ \\
\hline Sources: Authors'
\end{tabular}

Sources: Authors' analysis

Venter and Stedall's original South African financial product usages hierarchy was analysed and after interviews with financial services experts their model was revised. The revised model was used for the purposes of the analyses done in this article.

The responses obtained from respondents on whether they use specific financial products were dichotomous in nature. In order to facilitate comparability responses per product per life stage the respondents' information was converted to a 100 -point scale, where 100 represents the total number of respondents for the specific life stage group.

Various validity and reliability tests were performed on the data to ensure validity and reliability of the data, and no problems were encountered. The Cronbach's alpha reliability test was performed on the financial products, and it indicated an alpha value of 0.885 . In order to reject the null-hypothesis a $95 \%$ confidence level was set for the article.

Applying the adapted South African financial product usage model, the financial products included in AMPS were classified into the four levels. Although all the major financial products available in South Africa were included in AMPS, it is not a complete list of financial products available in South Africa.

To determine if usage at the different levels of the financial product usage hierarchy is significantly influenced by the life stages, chi-square tests were performed on each of the products included per life stage (namely: At-Home Singles, Young Independent Singles, SingleParent Family, Mature Singles, Young Couples, Young Family, Mature Family, Mature Couples). 
With the assistance of a statistician, chi-square tests were performed in order to determine if life stages influence movement between levels of the adapted financial product usage hierarchy. In order to perform this analysis the product with the highest usage rate for each life stage for each of the four hierarchical levels was selected for the purposes of the analysis.

\section{RESULTS AND DISCUSSION}

Before the effects of life stages on the use of financial products were analysed the Venter and Stedall (2010) South African financial product usages hierarchy was revised for the purposes of this study. The revised financial product usages hierarchy, discussed below, was used in this study.

\subsection{South African financial product usages hierarchy}

After interviews with experts in the financial services field the following adjustments were made to the original hierarchy. The first adjustment that was made is that automatic teller machine (ATM) and debit cards included in the original model as part of level one were excluded from the product list for this study. This is due the fact that these cards are not separate financial products but linked to other products, normally cheque or savings accounts.

As suggested by Venter and Stedall (2010), the expert interviews confirmed that savings accounts are popular among South Africans due to their low cost. For the purposes of this study savings accounts were moved from level 3 : basic savings products to level 1 : cash management products. Although Botha (2010) suggests that collective investments can be used for wealth management, the views of the expert respondents were that these products are mainly used for shorter-term savings; accordingly the products was moved from level 4 : wealth management products to level 3: basic savings products. Since the original hierarchy was developed a new product class was added to the survey data, namely Investment or deposit account. As these accounts were developed to provide an instrument that investors can use to save in at a slightly higher interest rate, these products are included in Level 3: basic savings accounts.

\subsection{South African product usage rating index}

Venter and Stedall (2010) developed a product usage rating index in order to determine the overall trends of product usage across different life stages. An adaptation of this index calculation was used to determine the weighted number of individuals who used products at each of the levels as a proportion of the total per level. In the original, index usage of each product in the level was ranked from highest to lowest; in this variation the actual numbers were used. The weight of each of the components (financial products) included in the level to calculate the overall index was determined by the overall usage of the component. TABLE 2 contains the results of the calculation representing the weighted number of individuals who made use of financial products per level; this was converted to percentages to facilitate easier interpretation.

Similar to previous studies, TABLE 2 indicates different usage patterns between different life stages as well as different levels. Generally the 'at-home singles' had the lowest usage of all financial products (percentage of group size) followed by the 'young independent singles' and 'single parent family'. 
TABLE 2: Product usage rating index (percentage)

\begin{tabular}{lcccc}
\hline \multicolumn{1}{c}{ LIFE STAGE } & $\begin{array}{c}\text { Level } \\
(\%)\end{array}$ & $\begin{array}{c}\text { Level 2 } \\
(\%)\end{array}$ & $\begin{array}{c}\text { Leve/3 } \\
(\%)\end{array}$ & $\begin{array}{c}\text { Level4 } \\
(\%)\end{array}$ \\
\hline At-Home Singles (AHS) & $24 \%$ & $11 \%$ & $1 \%$ & $2 \%$ \\
Young Independent Singles (yIS) & $33 \%$ & $12 \%$ & $2 \%$ & $2 \%$ \\
Single Parent Family (SPF) & $33 \%$ & $17 \%$ & $4 \%$ & $3 \%$ \\
Mature Singles (MS) & $34 \%$ & $20 \%$ & $6 \%$ & $2 \%$ \\
Young Couples (YC) & $36 \%$ & $23 \%$ & $8 \%$ & $5 \%$ \\
Young Family (yF) & $40 \%$ & $28 \%$ & $9 \%$ & $6 \%$ \\
Mature Families (MF) & $39 \%$ & $30 \%$ & $11 \%$ & $6 \%$ \\
\hline Mature Couples (MC) & $35 \%$ & $28 \%$ & $9 \%$ & $4 \%$ \\
\hline
\end{tabular}

Sources: Authors' analysis

As the 'young' groups are normally at the beginning phase of their uptake of financial products, with priorities focused on, for example, buying a car, transport, paying for rent, food and clothing, it is expected that they would have the lowest usage of financial products. Interestingly, the family groups had the highest uptake for most products, which could be due to the various financial needs families have to satisfy (Venter \& Botha 2014).

It is interesting to note that for all of the life stage groups there was a notable decline in the financial product usages when moving to a higher level. There is a constant and notable drop when considering the usage for the different levels of products. This confirms the lack of saving by individuals in South Africa, as very few individuals made use of wealth management products (level 4). Although the analysis of the number of individuals in each live stage who make use of products in the different levels indicates that life stage does influence product usage, this article's objective is to determine if the differences in use are statistically significant. These differences will be statistically analysed in the following section.

\subsection{Effect of life stage of product usage}

\section{Level 1: Cash management products}

The financial products included in this level are those aimed at providing short-term credit and facilitating transactions. TABLE 3 provides an indication of the usage of the product and if each of the eight life stages have a statistically significant impact on the usage of the product.

The analyses found that savings accounts are the financial product used by most households in South Africa. This finding supports the views expressed during the expert interviews that most South African households use these accounts as transactional accounts due to the low transaction costs of these accounts.

The fact that almost one in six households have retail store cards indicates that this should be a focus area for financial literacy programmes. It is therefore an opportune moment to have a financial literacy programme to make them aware of the risks and consequences of overindebtedness. 
TABLE 3: Cash management products

\begin{tabular}{lccc}
\hline \multicolumn{1}{c}{ Financial product } & $\begin{array}{c}\text { Usage index } \\
\text { score }\end{array}$ & $d f$ & $\chi^{2}$ \\
\hline Savings account & 64.9 & 7 & $359.54 * \star$ \\
Cheque account & 16.8 & 7 & $535.17^{\star *}$ \\
Credit card account & 8.7 & 7 & $309.84^{\star \star}$ \\
Retail store card & 15.9 & 7 & $193.33^{\star \star}$ \\
Mzanzi account & 1.9 & 7 & $102.41 * \star$ \\
\hline
\end{tabular}

Sources: Authors' analysis

** Statistically highly significant $(p<.01)$

The analysis indicates that life stages have a significant influence on the usage of all the financial products in the cash management product level. At-home singles have the lowest usage rate for all the products included in this level. Single-parent households and young independent singles also have much lower usage of the individual products in this level than the respondents in the other life stage groups.

The expert interviews indicated that a possible reason for low usage rate by young people (athome singles and young independent singles) could be the fact that they have limited financial needs and are still building a credit record, which will give them access to additional financial products.

\section{Level 2: Precautionary products}

Precautionary products are products that assist in preparing for an unexpected event. Although savings accounts can be used to keep money in reserve for unexpected events, certain accounts have been developed for specific unexpected events - for example, short-term insurance. The results of the statistical test done on precautionary products are provided in TABLE 4 .

\section{TABLE 4: Precautionary products}

\begin{tabular}{|c|c|c|c|}
\hline Financial product & $\begin{array}{c}\text { Usage index } \\
\text { score }\end{array}$ & $d f$ & $\chi^{2}$ \\
\hline Funeral insurance & 1.1 & 7 & $35.27 * \star$ \\
\hline Life cover policy & 32.4 & 7 & $202.06 * \star$ \\
\hline Medical aid scheme membership & 22.5 & 7 & $381.21 * *$ \\
\hline Medical insurance & 16.5 & 7 & $143.18 * \star$ \\
\hline Short-term insurance & 1.3 & 7 & $28.86 * \star$ \\
\hline
\end{tabular}

Sources: Authors' analysis

* Statistically significant $(p<.05)$

** Statistically highly significant $(p<.01)$ 
The analyses found that the precautionary product used most by households is life cover. These products aim to provide the family of the insured with money after the death of a person. During the last decade or more medical expenses have increased above the annual inflation rate, and various authors have indicated that medical insurance is therefore of the utmost importance for any household (Goodall \& King, 2010). The analysis indicates that only 23 of every 100 households are members of medical aid schemes. It is therefore clear that the majority of households are dependent on government to provide them with medical services, confirming the need for a national health insurance (National Treasury, 2013).

A general perception exists that South Africa has a very high crime rate, yet the study found that very few households have short-term insurance, which can be used to replace assets that are stolen.

The statistical analyses found that life stages have a highly significant influence on all five products included in this level of the hierarchy. Further analysis found that young independent singles' use of life-cover products, medical insurance and short-term insurance are materially lower than would be expected. The reason for this under-usage can possibly be found in the fact that these households are at the beginning of the financial independence life stage, are independent and no longer living with their parents and therefore possibly cannot afford these products yet.

The analysis of the use of life cover found that young people are not taking up life cover, with the highest uptake of life cover in the mature groups and young families, as could be expected. Obtaining life cover at a younger age will reduce the cost of life cover. Improving the financial literacy of people in this regard will assist people not only in making provision for their loved ones but also in reducing the cost of this provision.

\section{Level 3: Basic savings products}

TABLE 5 provides the result of the usage of basic savings products. The objective of basic savings products is to enable a person to save to meet the deposit requirement to buy certain assets, for example a house. The extremely low use of these products can be linked to the negative saving rate of households over the last couple of years (South African Reserve Bank, 2014).

TABLE 5: Basic savings products

\begin{tabular}{lccc}
\hline \multicolumn{1}{c}{ Financial product } & $\begin{array}{c}\text { Usage index } \\
\text { score }\end{array}$ & $d f$ & $\chi^{2}$ \\
\hline Collective investment funds (Unit trust or mutual funds) & 3.7 & 7 & 14.76 \\
Deposit account & 2.8 & 7 & $20.24^{\star}$ \\
Investment policy & 3.4 & 7 & $61.80 * *$ \\
\hline
\end{tabular}

Sources: Authors' analysis

* Statistically significant $(p<.05)$

$\star \star$ Statistically highly significant $(p<.01)$

Due to the very low usage of these product groups the statistical results should be interpreted with caution. The analysis revealed that there is no statistically significant difference in the use of collective investment funds between households in the different life stages. Interestingly, 
further analysis revealed that mature singles have a low usage rate of investment policies, while these products have a higher usage rate with mature and young families. These findings are consistent with the views of Pass et al. (2007), namely that households in the early lifecycle stages place a higher priority on products that are more secure, with lower risk and higher liquidity.

\section{Level 4: Wealth management products}

The final level on the savings product hierarchy is wealth management products. These products are long-term investment products aimed at maximising the household's wealth. The results of the statistical test performed on wealth management products are provided in TABLE 6 .

\section{TABLE 6: Wealth management products}

\begin{tabular}{lccc}
\hline \multicolumn{1}{c}{ Financial product } & $\begin{array}{c}\text { Usage index } \\
\text { score }\end{array}$ & $d f$ & $\chi^{2}$ \\
\hline Property: home loans & 1.9 & 7 & $65.34^{\star \star}$ \\
\hline Shares on the stock exchange & 1.2 & 7 & $37.54^{\star \star}$ \\
Motor vehicles (financing) & 1.5 & 7 & $37.84^{\star \star}$ \\
Durable goods & 3.1 & 7 & 315.8 \\
Endowment policies & 8.4 & 7 & $73.54^{\star \star}$ \\
\hline Retirement annuity & 4.3 & 7 & 14.66 \\
\hline
\end{tabular}

Sources: Authors' analysis

* Statistically significant $(p<.05)$

$\star \star$ Statistically highly significant $(p<.01)$

The most-used wealth management product is the endowment policy, followed by the retirement annuity. Despite expectations to the contrary, the analysis revealed that there is no statistically significant difference in the use of retirement annuity funds between the different life stages. The analyses indicated that only $8 \%$ of mature families and $7.61 \%$ of mature couples have a retirement annuity fund. The findings confirm those of National Treasury that the vast majority of South Africans do not have sufficient retirement provision (2007). The findings further support government's plan to introduce a social security system to which all employed people will have to make mandatory contributions.

The findings also support Goodall and King's (2010) view that mature families have an increased need for financial security, leading to an increased use of retirement annuities and endowment policies. As in the study by Pass et al. (2007), this study found that single persons do not make use of wealth management products, as their priorities lie with basic savings and obtaining credit to acquire assets.

\subsection{Influence of life stages on product selection}

The initial analysis done found that life stage does have a significant influence on usage of product on each of the levels of the product usage hierarchy. Baek and Hong (2004) found that as income and wealth increase during a person's life, the household requires more sophisticated 
products for purposes such as speculation and asset accumulation. With an increase in income, the priority saving motive of families expands from daily necessities to saving for precautionary or emergencies to children, retirement and holidays (Xiao \& Anderson, 1997). This is confirmed in this study by the fact that family households are the main users of financial products. The low levels of debt (namely, home loans and vehicle finance) can explain why mature families make less use of financial products, which would be in line with expectations.

In order to determine if life stages have a significant influence on the movement between the different levels a chi-square test was performed. The analysis found that there is a significant influence $\left(\chi^{2}(27)=290.41 ; p<.01\right)$.

Based on the results of the statistical tests performed, the null hypothesis (Hypothesis $1_{0}$ : Life stages do not have a significant influence on the financial products used by households for each of the financial product hierarchy levels) is rejected.

\section{SUMMARY AND CONCLUSION}

South Africa has a very low household savings rate, resulting in less than $10 \%$ of South Africans being able to retire financially independent. A reason for this lack of household saving is the fact that South Africans are over-indebted and the fact that households do not use financial products aimed to increase wealth. The aim of this article is to determine if life stages have a significant impact on the financial products people use in order to ensure financial independence.

An analysis of studies investigating financial product usage found a complex system at work when selecting a product, with Friedman's permanent income hypothesis playing an important role. The usage of each of the products in the financial product hierarchy, namely cash management products, precautionary products, basic savings products and wealth management products, was determined in order to establish if life stages do influence their usage. Various descriptions of life stages exist, but for the purposes of this study the eight life stages as described by the SAARF were used.

The quantitative research undertaken in this study aimed to determine whether life stages have a significant impact on South African households' selection of financial products. The findings indicate that as a person's age increases the number and level of product increases. The at-home singles group had the lowest usage rate of financial product, with the families groups having the highest usage rate.

Life stages had a significant impact on all the financial products included in the study. Life stages were also significant in determining movement from one level of the financial product usage hierarchy to the next.

The study concluded that regulators could focus on financial literacy programmes dealing with debt and the responsible use of debt by young couples and young families. The study found that only a small percentage of households have access to medical schemes, with single-parent families especially at risk mainly because of the financial burden placed on them by having only one income. The findings therefore suggest that alternative approaches to increase access to health care should be considered - for example, a national health system in South Africa could increase the number of people that have access to private medical care.

The very low usage of wealth management financial products is of special concern. Although some tax relief exists for people investing in pension funds and retirement funds, policymakers could 
consider introducing incentives that will encourage all South Africans to save for financial independence. A possible incentive could be a subsidy on the interest earned (effectively increasing the return on investment) on savings products aimed at increasing the long-term savings of South African households.

The study found support for the hypothesis that life stages have a significant influence on the products used by South African households. Increasing the use of wealth management products among the young will reduce the future cost of old age grants for the government and effectively the taxpayers in South Africa.

Additional research is required to determine which independent variable - for example, age, income or life stage - is the best predictor of financial product usage. This research will enable policymakers to better target any attempts to increase household saving, enabling more than $10 \%$ of the South African population to retire financially independent.

In conclusion, Nelson Mandela said:

"There is no easy walk to freedom anywhere, and many of us will have to pass through the valley of the shadow of death again and again before we reach the mountaintop of our desires."

This is also true of financial freedom, and this study aimed to identify where interventions should be targeted to bring some light to the valley of the shadow of death in personal finances.

\section{LIST OF REFERENCES}

Ando, A. \& Modigliani, F. (1963). The life cycle hypothesis of savings; Aggregate implications and tests. American Economic Review, 53, pp. 55-84.

Baek, $\varepsilon$. \& Hong, G-S. (2004). Effects of family life cycle stages on consumer debts. Journal of Family and Economic /ssues, 25(3), pp. 359-385.

Bijmolt, T.H.A., Passass, L.J. \& Vermunt, J.K. (2004). Country and consumer segmentation: Multi-level latent class analysis of financial product ownership. International Journa/ of Research in Marketing, 21(4), pp. 323-340.

Botha, M. (2010). Corporate and personal financial planning. Durban: LexisNexis. Durban [CD-ROM]

Browning, M. \& Lusardi, A. (1996). Household saving: Micro theories and micro facts. Journal of Economic Literature, 34(4) pp., 1797-1855.

Canova, L., Rattazzi, A.M.M. \& Webley, P. (2005). The hierarchical structure of saving motives. Journal of Economic Psychology, 26(1), pp. 21-34.

De Clercq, B. \& Venter, J.M.P. (2009). Factors influencing a prospective chartered accountant's level of financial literacy: an exploratory study. Meditari, 17(2), pp. 47-60.

Devaney, S.A., Anong, S.T. \& Whirl, S.E. (2007). Household savings motives. The Journal of Consumer Affairs, 41 (1), pp. 174

Eriksson, K. \& Hermansson, C. (2014). Searching for new saving behavior theories. International Journal of Bank Marketing, 32(4), pp. 279-299.

Fethke, C.C. (1998). Life-Cycle Models of Saving and the Effect of the Timing of Divorce on Retirement Economic Weil-Being. Journal of Gerontology, 44 (3), pp. S121-S128. 
Fisher, I. (1930). The theory of interest. London: Macmillan.

Fisher, P.J. \& Anong, S., T. (2012). Journal of Financial Counselling and Planning, 23(1), pp. 63 -79.

Friedman, M. (1957). A theory of the consumption function. Princeton, NJ: Princeton University Press.

Goodall, B. \& King, R. (2010). Tax and Investment easyguide. 2010/2011 ed. Durban: LexisNexis

Butterworths. [CD].

Grosh, M. \& Glewwe, P. (2000). Designing Household Survey Questionnaires for Developing Countries: Lessons from 15 Years of the Living Standards Measurement Study. The World Bank.

Katona, G. (1975). Psychological Economics, Elsevier, New York, Ny.

Keynes, J.M. (1936). The general theory of employment, interest and money. London: Macmillan.

Lindqvist, A. (1981). A note on the determinants of household saving behavior. Journal of Economic Psychology, 1(1), pp. 39-57.

Masimela, \&. \& Kiniki, S. (2009). South African contributing towards a pension: evidence from the Labour Force Survey. Pretoria.

Modigliani, F. \& Brumberg, R. (1954). Utility analysis and the consumption function. An interpretation of cross-section data. In K.K Kurihara (Ed.), Post Keynesian economics. New Brunswick, NJ: Rutgers University Press.

Murphy, P. \& Staples, W. (1979). A modernized family life-cycle. Journal of Consumer Research, 6, pp. 12-22.

National Treasury. (2013). Budget Review 2013. Pretoria: State Printers.

Pass, L.J. \& Bijmolt, T.H.A \& Vermunt, J.K. (2007). Acquisition patterns of financial products: A longitudinal investigation. Journal of Economic Psychology, 28, pp. 229-241.

SAARF (South African Advertising Research Foundation). (2014). SAARF AMPS. http://www.saarf.co.za/amps-presentations/2013/ [Accessed 30 July 2014]

Simleit, C., Keeton, G. \& Botha, F. (2011). The determinants of household savings in South Africa. Studies in Economics and Econometrics, 35(3), pp. 1-20.

South African Reserve Bank. (2014). Quarterly Bulletin June 2014. Pretoria.

Stafford, E.F., Kasulis, J.J. \& Lusch, R.L. (1982). Consumer behavior in accumulating household financial assets. Journal of Business Research, 10(4), pp. 397-417.

The Financial Services Board. (2011). Financial Literacy in South Africa: Results of an 0ECD/INFE pilot study. Pretoria

Venter, J.M.P. (2014). Are South African financial advisor addressing the estate planning objectives that are important to their client? Journal Risk Governance \& Control: Financial Markets \& Institutions, 4(2), 125-131

Venter, J.M.P. \& Stedall, C. (2010). The influence of life stages on the usage of financial products by South African households. SAAA conference June 2010. Pretoria South African Accounting Association.

Venter, J.M.P. \& Botha, A. (2014). Analysing the financial needs addressed by South African consumers when using credit products. Journal Risk Governance \& Control: Financial Markets \& Institutions, 4(2), 101-110 
Warneryd, K.-E. (1999). The psychology of saving: A study of economic psychology. Northampton, UK: Edward Elgar Publishing.

Wheelwright, V. (2003). Ageing: a personal future perspective. Foresight, 5(6), pp. 61-68.

Wilkie, W.L. (1994). Consumer Behaviour. New York: Wiley \& Sons, Inc.

Xiao, J.J., \& Anderson, J.G. (1997). Hierarchical financial needs reflected by household financial asset shares. Journal of Family and Economic Issues, 18, pp. 333-355. 